\title{
Flumazenil therapy for a gabapentin-induced coma: a case report
}

\author{
M. Masciullo ${ }^{1,2}$, F. Pichiorri $^{1}$, G. Scivoletto ${ }^{1,2^{*}}$, C. Foti $^{3}$ and M. Molinari ${ }^{1}$
}

\begin{abstract}
Background: Spasticity and neuropathic pain are common in patients after spinal cord injury and negatively affect patients' quality of life. Gabapentin and baclofen are frequently used to treat these conditions. We present a flumazenil-reversed gabapentin-induced coma case, which, to our knowledge, is the second one described in scientific literature.

Case presentation: A 70-year-old Caucasian man was admitted to our neurorehabilitation ward following a fall with cervical trauma that resulted in immediate tetraplegia. During his stay, he suffered from lower limb pain, both neuropathic and due to severe spasticity. Gradual baclofen and gabapentin administration was prescribed, with reduction in both pain and spasticity. One morning, the patient was found unresponsive, with a Glasgow Coma Score of 3. Head computerized tomography, electrocardiogram, electroencephalogram, vital signs, blood tests, breathing, and blood oxygenation were normal. Renal and liver failure were ruled out. Intravenous $0.25 \mathrm{mg}$ of flumazenil (Anexate) was administered, resulting in complete neurocognitive recovery with a Glasgow Coma Score of 15.

Discussion and conclusions: This case report highlights the importance of the individual response to certain pharmacological agents and suggests that further studies need to be conducted both on flumazenil and gabapentin pharmacodynamics to better understand their molecular-receptor activity, and on possible multiple flumazenil mechanisms of action, beyond its classical strict benzodiazepine antagonist action.
\end{abstract}

Keywords: Case report, Spinal cord injury, Spasticity, Neuropathic pain, Gabapentin, Baclofen, Flumazenil

\section{Background}

Following spinal cord injury (SCI), neuroplasticity, which involves neuronal, structural, and functional responses, is essential for recovery of neurological function, but the dark side of this neuroplasticity can be the development of neuropathic pain and spasticity. These common disabling conditions negatively affect mood, sleep, quality of life, and participation in activities, such as active recreation and employment. Neuropathic pain is present in $50-60 \%$ and spasticity in about $70 \%$ of individuals living with a SCI [1]. Gabapentin and baclofen are frequently

\footnotetext{
*Correspondence: g.scivoletto@hsantalucia.it

1 Spinal Cord Unit, IRCCS S. Lucia Foundation, Rome, Italy

Full list of author information is available at the end of the article
}

used in the treatment of spasticity and neuropathic pain [2-6].

The present work describes a flumazenil-reversed gabapentin-induced coma case which, to our knowledge, is only the second one described in scientific literature, and suggests a possible expansion of flumazenil's therapeutic indications beyond benzodiazepines.

\section{Case presentation}

The case involves a 70-year-old Caucasian man who was admitted to our neurorehabilitation ward (Neurorehabilitation 1, Santa Lucia Foundation, Rome, Italy) following a fall with cervical trauma that resulted in immediate tetraplegia (AIS A, C5 level, according to the American Spinal Injury Association classification). Neurosurgical intervention was ineffective in decompressing the spinal cord, original author(s) and the source, provide a link to the Creative Commons licence, and indicate if changes were made. The images or other third party material in this article are included in the article's Creative Commons licence, unless indicated otherwise in a credit line to the material. If material is not included in the article's Creative Commons licence and your intended use is not permitted by statutory regulation or exceeds the permitted use, you will need to obtain permission directly from the copyright holder. To view a copy of this licence, visit http://creativecommons.org/licenses/by/4.0/. The Creative Commons Public Domain Dedication waiver (http://creativeco mmons.org/publicdomain/zero/1.0/) applies to the data made available in this article, unless otherwise stated in a credit line to the data. 
and no neurological recovery occurred. His medical history included stent-treated myocardial infarction, cholecystectomy, double biliary tract stenting, no smoking, no diabetes, sporadic and moderate alcohol intake prior to hospital admission, no renal or liver dysfunction, no epilepsy, and untreated spondylogenic myelopathy. Since cervical trauma, the patient had experienced neurogenic bladder and neurogenic bowel dysfunction. Chronic iron deficiency was observed in consequence to reduction in protein intake. The patient was a retired architect, and he was married, with no children. He did not have any substance abuse history.

On admission, the patient was alert, cooperative, and well oriented; he was classified as having tetraplegia (AIS A level C5) with marked spasticity in the lower limbs. Stage I sacral, stage III right heel, and stage II left heel bedsores were noted. Abdomen was plane, without any pain or discomfort with both superficial and deep palpation. Thorax was hypomobile with preserved vesicular murmur on pulmonary fields. Cardiac auscultation revealed a rhythmic heart rate, with free pauses and no abnormal heart sounds. The patient wore a condom catheter, which was removed to start the management of the neurogenic bladder through nurse-managed intermittent catheterization. Vital signs were blood pressure (BP) 113/65 mmHg, heart rate (HR) 52 beats per minute, oxygen saturation $\left(\mathrm{SaO}_{2}\right) 98 \%$, and temperature $(\mathrm{T}) 36^{\circ} \mathrm{C}$.

During his stay, he suffered from lower limb pain both neuropathic and due to severe spasticity, which is a frequent event in patients with spinal cord injury. A common and effective pharmacological approach for neuropathic pain and, in part, for spasticity, consists of gabapentin administration [2-5, 7]. Complete pharmacological therapy prior to the diagnosis was the following: intravenous sodium chloride $0.9 \% 500 \mathrm{ml}$ twice per day, oral vancomycin $500 \mathrm{mg}$ one-fourth of a vial four times per day, oral baclofen $25 \mathrm{mg}$ three times per day (started on 21 December 2019), oral amiodarone (Cordarone) $200 \mathrm{mg}$ per day, oral gabapentin (Neurontin) $300 \mathrm{mg}$ twice per day, oral pantoprazole $40 \mathrm{mg}$ per day, oral acetilsalicilic acid (Cardioaspirin) $100 \mathrm{mg}$ per day, oral amlodipine $2.5 \mathrm{mg}$ per day, oral potassium $600 \mathrm{mg}$ twice per day, oral macrogol for bowel regularity, oral furosemide $25 \mathrm{mg}$ per day, oral simethicone $80 \mathrm{mg}$ three times per day, oral silodosin $8 \mathrm{mg}$ per day, oral bisoprolol $25 \mathrm{mg}$ per day, intravenous iron supplement $5 \mathrm{mg} / 5 \mathrm{ml}$ one vial per day, subcutaneous fondaparinux $2.5 \mathrm{mg} / 0.5 \mathrm{ml}$ per day, enemas to ensure regular defecation, oral probiotics, and oral zolpidem $10 \mathrm{mg}$ only if needed to sleep (last intake more than 20 days before the onset of coma). Gabapentin was started on 15 January 2020 (orally $100 \mathrm{mg}$ three times per day) and interrupted after 11 days because of drowsiness. Unfortunately, lower limb pain was so intense that gabapentin was once again prescribed on 24 February 2020, starting with a $300 \mathrm{mg}$ dose in the evening. On 14 March 2020, dosage was increased to $300 \mathrm{mg}$ twice a day (well tolerated by the patient), and gabapentin administration continued with this dosage until 22 June 2020.

On 22 June 2020, at approximately 7 am, the first round of drug administration took place and the patient received intravenous administration of sodium chloride $(500 \mathrm{ml})$, an oral quarter of a $500 \mathrm{mg}$ vial of vancomycin (for a Clostridioides difficile infection in resolution), oral $25 \mathrm{mg}$ of baclofen, oral $300 \mathrm{mg}$ of gabapentin, oral $40 \mathrm{mg}$ of pantoprazole, oral $600 \mathrm{mg}$ of potassium chloride, oral $25 \mathrm{mg}$ of furosemide, oral $80 \mathrm{mg}$ of simethicone, and intravenous $5 \mathrm{mg}$ of iron supplement. The patient was alert and compliant and did not report any discomfort. After 1 hour, at $8 \mathrm{am}$, breakfast was distributed, and at that moment the nurse found the patient asleep and did not manage to wake him up through vocal recall nor by pain induction (nipple squeezing). Medical personnel were informed and immediately examined the patient. The patient was breathing normally, eyes closed. It was not possible to wake him up in any way. Vital signs were within normal range (blood pressure $125 / 73 \mathrm{mmHg}$, heart rate $50 \mathrm{bpm}, \mathrm{SaO}_{2} 97 \%$, body temperature $36.5^{\circ} \mathrm{C}$ ), EEG showed normal alpha activity with basic rhythm at seven to eight cycles per second on the posterior and middle regions, symmetrical, medium voltage, stable. Urgent head CT did not show any sign of bleeding, urgent blood tests were normal without any sign of acute renal or liver failure or sign of infection (details are provided further on), and EKG was normal (apart from the known $\mathrm{Q}$ wave due to the previous myocardial infarction). The patient was clinically unresponsive with a Glasgow Coma Score (GCS) of 3. Intravenous hydration was administered, and a permanent urinary catheter was inserted to ensure renal function. At $11 \mathrm{am}$, after approximately 3 hours of coma, intravenous $0.20 \mathrm{mg}$ flumazenil (Anexate) was administered. After 30 seconds, the patient opened his eyes and returned to his usual neurocognitive state, with a GCS of 15 . As a precautionary measure, food supply was suspended for the following 6 hours. The patient was closely monitored for the rest of the day and did not present any other loss-of-consciousness episodes. Gabapentin dosage was reduced to $100 \mathrm{mg}$ twice a day. The next day, the patient resumed his normal rehabilitation schedule.

Detailed results of blood tests performed on 22 June 2020:

White blood cells (WBC) 7.8 [n.r. 4.00-10.00] $\times 10^{3} /$ $\mathrm{mm}^{3}$, hemoglobin (HGB) 9.10 [n.r. 13-17] g/dL, hematocrit (HCT) $28.30 \%$ [n.r. 40-49\%], platelets (PLT) $185[150-500] \times 10^{3} / \mathrm{mm}^{3}$, mean corpuscular volume 
(MCV) 83.00 [n.r. 80-100] $\mu^{3}$, mean corpuscular hemoglobin $(\mathrm{MCH}) 26.80$ [n.r. 27-32] pg, mean corpuscular hemoglobin concentration (MCHC) 32.10 [n.r. 32-36] g/ $\mathrm{dL}$, mean platelet volume (MPV) 10.50 [n.r. 6-11] $\mu^{3}$, procalcitonin (PCT) 0.19\% [n.r. 0.15-0.50\%], red cell distribution width (RDW) $17.60 \%$ [n.r. 11-16\%], blood urea 28 [n.r. 16.6-48.5] mg/dL, creatinine 1.13 [n.r. 0.7$1.2] \mathrm{mg} / \mathrm{dL}$, estimated glomerular filtration rate (eGFR) 65.4 [n.r. > 60] ml/min, glycemia 80 [n.r. 74-105] mg/dL, aspartate transaminase (AST) 20 [n.r. < 40] U/L, alanine aminotransferase (ALT) 20 [n.r. 1-41] U/L, gammaglutamyl transferase (GGT) [n.r. < 60] $65 \mathrm{U} / \mathrm{L}$, sodium 137 [n.r. 136-145] $\mathrm{mmol} / \mathrm{L}$, potassium 4.6 [n.r. 3.55.10] $\mathrm{mmol} / \mathrm{L}$, and C-reactive protein (CRP) 18.7 [n.r. $<5] \mathrm{mg} / \mathrm{L}$; CRP was gradually returning within normal range after an increase due to Clostridioides difficile (on 15 June, CRP was $50.9 \mathrm{mg} / \mathrm{L}$ ).

During the following 7 months, the patient stayed in our ward for rehabilitation and did not experience any other similar episode. He was discharged on 18 February 2021.

\section{Discussion and conclusions}

This case report describes a flumazenil-reversed gabapentin-induced coma in an adult subject without specific organ dysfunction; to our knowledge, it is the second one described in scientific literature.

Gabapentin is an antiepileptic drug, widely used for the treatment of neuropathic pain and spasticity, which are frequent in patients with spinal cord injury [2-5]. It has a structure similar to that of GABA but does not bind to those receptors. The exact mechanism of the drug is relatively unknown, but it is thought to act at the alpha- $2 \delta 1$ subunit of voltage-dependent calcium channels, thus inhibiting calcium currents [8]. Flumazenil (Ro15-178) is a 1,4-imidazobenzodiazepine with highly specific and competitive antagonist activity at benzodiazepine receptor [9]. It binds to the extracellular surface of GABA-A receptors and competitively displaces benzodiazepine molecules, preventing further benzodiazepine binding [10]. To our knowledge, only three gabapentin-induced coma cases have been reported: Buttler et al. [11], Dogukan et al. [12], Abdennour et al. [13]. The first two clinical cases were adults with known history of kidney failure, and the third one was a woman with diffuse subarachnoid hemorrhage complicated by seizures. As in the present case report, one of these patients was treated with flumazenil (in addition to dialysis) [11].

This case differs from the previous ones because this patient did not have renal failure (which could have caused a difficult urinary excretion of gabapentin), did not suffer from acute brain injury (as demonstrated by head CT), and did not suffer from cardiac arrhythmias (as demonstrated by EKG). Electrolyte imbalances were excluded by the blood panel. The patient was clinically in a coma state, but the EEG was normal. Therefore, the only plausible explanation to justify this sudden loss of consciousness could be a particular receptor sensitivity of the patient to the GABAergic activity of gabapentin or an accumulation effect or a mutual potentiation between baclofen and gabapentin. The clinical presentation was considered as a "benzodiazepine-like" overdose; therefore, an off-label intravenous injection of flumazenil was performed. Although flumazenil is considered a benzodiazepine-specific antidote, other literature case reports describe its use as an antidote for other drugs such as promethazine [14].

This case report highlights the importance of the individual response to certain pharmacological agents and suggests that further studies need to be conducted both on flumazenil and gabapentin pharmacodynamics to better understand their molecular-receptor activity, and on possible multiple flumazenil mechanisms of action, beyond its classical strict benzodiazepine antagonist action.

\section{Abbreviations}

SCI: Spinal cord injury; GCS: Glasgow Coma Score; CT: Computerized tomography; EKG: Electrocardiogram; EEG: Electroencephalogram; AIS: ASIA Impairment Scale; $\mathrm{SaO}_{2}$ : Arterial oxygen saturation; GABA: Gamma-aminobutyric acid; P.O.: Per Os, oral administration.

\section{Acknowledgements}

We thank our patient for giving us the opportunity to elaborate this work.

\section{Authors' contributions}

MMa conducted the literature search and wrote the manuscript draft, GS compared literature findings with the case's data and clinical presentation, FP conducted neurophysiological tests on the patient and interpreted data according to clinical presentation, MMo coordinated and supervised clinical management and ethical conduct, and CF revised the final manuscript. All authors read and approved the final manuscript.

\section{Funding}

Partially funded by the Eranet-Neuron Grant to G.S.

Availability of data and materials

Data available upon reasonable request.

\section{Declarations}

Ethics approval and consent to participate

No ethical violation occurred in the information management.

\section{Participation consent}

Not applicable.

\section{Consent for publication}

Written informed consent was obtained from the patient for publication of this case report and any accompanying images. A copy of the written consent is available for review by the Editor-in-Chief of this journal. 


\section{Competing interests}

Authors do not have any competing interests.

\section{Author details}

${ }^{1}$ Spinal Cord Unit, IRCCS S. Lucia Foundation, Rome, Italy. ${ }^{2}$ SPInal REhabilitation Lab (SPIRE), IRCCS Fondazione Santa Lucia, Rome, Italy. ${ }^{3}$ Physical and Rehabilitation Medicine, University of Rome "Tor Vergata", Rome, Italy.

Received: 10 September 2020 Accepted: 23 March 2021

Published online: 09 May 2021

\section{References}

1. Finnerup NB. Neuropathic pain and spasticity: intricate consequences of spinal cord injury. Spinal Cord. 2017;55(12):1046-50. https://doi.org/10. 1038/sc.2017.70.

2. To TP, Lim TC, Hill ST, et al. Gabapentin for neuropathic pain following spinal cord injury. Spinal Cord. 2002;40(6):282-5. https://doi.org/10.1038/ sj.sc. 3101300

3. Tai Q, Kirshblum S, Chen B, Millis S, Johnston M, DeLisa JA. Gabapentin in the treatment of neuropathic pain after spinal cord injury: a prospective, randomized, double-blind, crossover trial. J Spinal Cord Med. 2002;25:2, 100-105. https://doi.org/10.1080/10790268.2002.11753609

4. Gruenthal M, Mueller M, Olson WL, Priebe MM, Sherwood AM, Olson WH. Gabapentin for the treatment of spasticity in patients with spinal cord injury. Spinal Cord. 1997;35(10):686-9. https://doi.org/10.1038/sj.sc.31004 81.

5. Rabchevsky AG, Patel SP, Duale H, Lyttle TS, O'Dell CR, Kitzman PH. Gabapentin for spasticity and autonomic dysreflexia after severe spinal cord injury. Spinal Cord. 2011:49(1):99-105. https://doi.org/10.1038/sc.2010.67.

6. Chang E, Ghosh N, Yanni D, Lee S, Alexandru D, Mozaffar T. A review of spasticity treatments: pharmacological and interventional approaches.
Crit Rev Phys Rehabil Med. 2013;25(1-2):11-22. https://doi.org/10.1615/ CritRevPhysRehabilMed.2013007945.

7. Teasell RW, Mehta S, Aubut JA, et al. A systematic review of pharmacologic treatments of pain after spinal cord injury. Arch Phys Med Rehabil. 2010;91(5):816-31. https://doi.org/10.1016/j.apmr.2010.01.022.

8. Chang E, Ghosh N, Yanni D, Lee S, Alexandru D, Mozaffar T. A review of spasticity treatments: pharmacological and interventional approaches. Crit Rev Phys Rehabil Med. 2013;25(12):1122. https://doi.org/10.1615/ CritRevPhysRehabilMed.2013007945.

9. O'Sullivan GF, Wade DN. Flumazenil in the management of acute drug overdosage with benzodiazepines and other agents. Clin Pharmacol Ther 1987;42(3):254-9. https://doi.org/10.1038/clpt.1987.143.

10. Sivilotti ML. Flumazenil, naloxone and the "coma cocktail." Br J Clin Pharmacol. 2016;81(3):428-36. https://doi.org/10.1111/bcp.12731.

11. Butler TC, Rosen RM, Wallace AL, Amsden GW. Flumazenil and dialysis for gabapentin-induced coma. Ann Pharmacother. 2003;37(1):74-6. https:// doi.org/10.1345/aph.1C242.

12. Dogukan A, Aygen B, Berilgen MS, Dag S, Bektas S, Gunal Al. Gabapentin-induced coma in a patient with renal failure. Hemodial Int. 2006;10(2):168-9. https://doi.org/10.1111/j.1542-4758.2006.00089.x

13. Abdennour L, Sanchez-Peña P, Galanaud D, Navarro V, Weiss N, Puybasset L. Gabapentin-induced coma: a MR-spectrometry analysis. Neuropsychiatr Dis Treat. 2007;3(5):695-702.

14. Plant JR, MacLeod DB. Response of a promethazine-induced coma to flumazenil. Ann Emerg Med. 1994;24(5):979-82. https://doi.org/10.1016/ s0196-0644(94)70217-9.

\section{Publisher's Note}

Springer Nature remains neutral with regard to jurisdictional claims in published maps and institutional affiliations.
Ready to submit your research? Choose BMC and benefit from:

- fast, convenient online submission

- thorough peer review by experienced researchers in your field

- rapid publication on acceptance

- support for research data, including large and complex data types

- gold Open Access which fosters wider collaboration and increased citations

- maximum visibility for your research: over $100 \mathrm{M}$ website views per year

At BMC, research is always in progress.

Learn more biomedcentral.com/submissions 